Article

\title{
Removal of Fluoride and Arsenate from Aqueous Solutions by Aluminum-Modified Guava Seeds
}

\author{
Sarai Ramos-Vargas ${ }^{1}$ (), Ruth Alfaro-Cuevas-Villanueva ${ }^{2}$, Rafael Huirache-Acuña ${ }^{3}$ and \\ Raúl Cortés-Martínez ${ }^{1, *(\mathbb{D})}$ \\ 1 Facultad de Químico Farmacobiología, Universidad Michoacana de San Nicolás de Hidalgo, Tzintzuntzan \\ 173 Col. Matamoros, Morelia C.P. 58240, Michoacán, Mexico; sarv_3@hotmail.com \\ 2 Instituto de Investigaciones en Ciencias de la Tierra, Universidad Michoacana de San Nicolás de Hidalgo, \\ Edificio U, C.U., Morelia C.P. 58060, Michoacán, Mexico; racv11@gmail.com \\ 3 Facultad de Ingeniería Química, Universidad Michoacana de San Nicolás de Hidalgo, C.U., Morelia C.P. \\ 58060, Michoacán, Mexico; rafael_huirache@yahoo.it \\ * Correspondence: raulcortesmtz@gmail.com; Tel.: +52-443-314-2152
}

Received: 25 August 2018; Accepted: 20 September 2018; Published: 2 October 2018

check for updates

Featured Application: The adsorbent materials under study could have a potential use for the decontamination of groundwater with high levels of arsenic and fluoride. It could be particularly suitable for application in water treatment for small communities.

\begin{abstract}
The contamination of groundwater by arsenic and fluoride is a major problem worldwide, causing diseases in the population that uses these waters for their consumption. Therefore, the removal of these types of pollutants from groundwater is a very important issue. In this work, the removal of arsenate and fluoride from aqueous solutions by using aluminum-modified guava seeds (Al-GSs) was evaluated. Batch-type adsorption experiments were carried out with aqueous solutions of $\mathrm{As}(\mathrm{V})$ and $\mathrm{F}^{-}$and Al-GSs. The kinetic and equilibrium parameters of adsorption were determined, as well as the effects of adsorbent dose and $\mathrm{pH}$. The adsorbent was characterized by scanning electron microscopy and infrared spectroscopy in order to determine its morphology and the functional groups present in the material. The results showed that hydroxyl and carboxyl are the main groups involved in the adsorption of $\mathrm{As}(\mathrm{V})$ and $\mathrm{F}^{-}$. The fluoride adsorption kinetics indicate that the equilibrium time was reached at $150 \mathrm{~min}$ and it can be described by the Lagergren model, while for $\mathrm{As}(\mathrm{V})$ the equilibrium time was lower $(120 \mathrm{~min})$ and the kinetic data were fitted well to the pseudo-second-order model. The Langmuir-Freundlich model can describe the adsorption equilibrium data in all cases. The fluoride adsorption capacity by Al-GS was $0.3445 \mathrm{mg} / \mathrm{g}$, and for $\mathrm{As}(\mathrm{V})$ it was $4 \mathrm{mg} / \mathrm{g}$. It can be established that the removal of arsenates and fluoride in Al-GSs is due to chemisorption on a heterogeneous surface.
\end{abstract}

Keywords: fluoride; arsenic; biosorption; guava seeds; isotherms

\section{Introduction}

Groundwater contamination owing to arsenic (As) and fluoride $\left(\mathrm{F}^{-}\right)$is an important problem on which special attention must be paid. The challenges to be discussed and solved on this subject are varied, and therefore it is quite important to investigate novel and effective methods for their remediation [1]. For instance, $\mathrm{F}^{-}$is present in groundwater in several aquifers around the world in levels ranging from 1 to $30 \mathrm{mg} / \mathrm{L}$. It has been reported that if $\mathrm{F}^{-}$is present in drinking water at concentrations between 0.5 and $1 \mathrm{mg} / \mathrm{L}$, it could have beneficial effects to health, providing substantial protection against dental caries [2]. If higher levels of $\mathrm{F}^{-}$are present (from 1.5 to $2 \mathrm{mg} / \mathrm{L}$ ), 
then consumption of these waters may lead to dental fluorosis. From 3 to $6 \mathrm{mg} / \mathrm{L}$ of fluoride, skeletal fluorosis may appear, and at higher fluoride levels $(>10 \mathrm{mg} / \mathrm{L})$ crippling skeletal fluorosis can be developed [3,4]; these types of fluorosis are irreversible, and no treatment can eliminate symptoms definitively. Keeping fluoride intake within safe levels is the only way to prevent these diseases $[5,6]$. People in several countries around the world are facing problems of high fluoride levels in drinking water; these problems are more severe and intense depending on different factors, like the geographical and economic status of the affected communities [7]. The World Health Organization (WHO) guidelines for drinking water quality have established that, for areas with a warm climate, fluoride concentration in water should remain below $1 \mathrm{mg} / \mathrm{L}$, while this concentration could be raised up to $1.2 \mathrm{mg} /$ for areas with a cold climate [3]. In developing countries this problem is more acute, particularly in small urban communities and rural areas $[5,8]$.

On the other hand, arsenic content in drinking water is also a worldwide concern, and it represents a great threat to human health. Levels above $10 \mu \mathrm{g} / \mathrm{L}$ of arsenic, which is the maximum level recommended by the $\mathrm{WHO}$, have been reported in drinking water from several countries like India, Bangladesh, Taiwan, Mongolia, Chile, Mexico, and the United States. Chronic exposure to arsenic can induce skin cancer, or it can cause damages to the kidneys, lungs, and bladder, as well as disorders of cardiovascular and neurological systems [9]. Arsenic can be found in aquatic environments in the oxidation states $+\mathrm{III}$ and $+\mathrm{V}$, depending on the redox conditions. The As(III) species is the most toxic and it is more mobile than $\mathrm{As}(\mathrm{V})$ species [10]. Usually, arsenic in the oxidation state $+\mathrm{V}$ predominates in surface waters, while arsenic in the oxidation state $+\mathrm{III}$ is the main species found in groundwater, particularly for deep aquifers. However, arsenic in both oxidation states can be found in groundwater due to changes in redox conditions and biological activity [11].

Arsenic and fluoride coexistence has been reported in groundwater samples from aquifers in different countries, with concentrations up to $5300 \mu \mathrm{g} / \mathrm{L}$ and $29 \mathrm{mg} / \mathrm{L}$ for As and $\mathrm{F}^{-}$, respectively [12]. It has been reported synergistic adverse effects in mouse kidney and liver at low arsenic and fluoride concentrations [12], but they are far from being completely understood. Such co-occurrence of arsenate and fluoride ions has been reported in some industrial wastewaters, like those discharged from metallurgy and electroplating industries. Consequently, removal of arsenic and fluoride from drinking water is of great importance in order to optimize costs and simplify treatment processes, especially when these two ions are present simultaneously in contaminated aquifers. [13].

Arsenic and fluoride removal from water can be achieved by different methods, including chemical treatment, electrochemical methods, membrane technologies, and ion exchange processes. However, the high costs, difficulty in operation, and the high solute concentration in water are some factors that restrict the implementation of these type of technologies [13]. The adsorption process is preferred when arsenic and fluoride removal from water is required in a small-scale system owing to its high efficiency, low cost, and the relative easiness in operation of the system. Moreover, the adsorption process is found to be environmentally friendly, economical, and suitable for single families and small communities. Many studies have reported the possible utilization of conventional adsorbents for arsenic or fluoride removal, separately, like modified activated carbon, zeolites, clays, activated alumina, titanium dioxide, etc., with different degrees of success [14-17]. Recently, more attention has been paid by the scientific community in using diverse naturally occurring biosorbents in sorption processes since this type of adsorbents offers advantages of sludge minimization, high efficiencies when diluted solutions are treated, regeneration of biosorbent, and low cost [18].

However, few studies have reported simultaneous removal of $\mathrm{As}(\mathrm{V})$ and $\mathrm{F}^{-}[12,13,19,20]$. Arsenate $(0.9 \mathrm{mg} / \mathrm{g})$ and fluoride $(0.5 \mathrm{mg} / \mathrm{g})$ adsorption capacities have been reported when goethite is used to remove these ions from groundwater simultaneously. Furthermore, a decrease in fluoride removal from 82 to $28 \%$ was reported when arsenic was present in the solution at a concentration of $1 \mathrm{mg} / \mathrm{L}$ [12]. It has been reported [13] that aluminum and iron binary oxide is suitable for simultaneous As and $\mathrm{F}$ removal and found that the adverse effects of competitive adsorption between $\mathrm{As}(\mathrm{V})$ and $\mathrm{F}$ were significantly reduced by using binary oxide rather than the single $\mathrm{Al}$ and Fe oxides. Jing et al. [12] 
found that arsenate and fluoride adsorption capacities of an activated carbon modified with lanthanum and titanium oxides were pronouncedly higher than some aluminum-based adsorbents for synthetic water and real contaminated groundwater. Therefore, the purpose of Al modification of guava seeds is to enhance fluoride sorption capacity since it has been reported the affinity of these ions to Aluminum-type adsorbents. Furthermore, in our previous studies, we have reported a low fluoride sorption capacity of guava seeds [8].

The use of conventional adsorbents for arsenic and fluoride removal from groundwater could be expensive and ineffective. Consequently, the use of alternative adsorbents is of great relevance, such as products of biological origin, or wastes and by-products from industrial and agricultural activities [21]. These agricultural waste materials used as biosorbents have some advantages over conventional adsorbents because they are abundant, available, inexpensive, and may act as complexing agents due to their physicochemical characteristics and particular structure [21]. Particularly, lignocellulosic materials derived from agricultural wastes have been considered as efficient adsorbents due to their high cellulose, hemicellulose and lignin content and because of their large scale generation and low cost.

Guava (Psidium guajava) seeds are considered as a solid waste produced in great quantities by agricultural and industrial activities in Mexico. Recent increases in guava production and consumption have led to the production of large amounts of guava seed waste that requires disposal; this could be have been mitigated by recycling this waste as an inexpensive source of biomass [22]. Guava seeds have structural properties, like high content of cellulose, lignin and protein that make them suitable for their use as a biosorbent, particularly for anionic contaminants present in water. These properties are due to the presence of various functional groups on its surface such as amines, hydroxyl, carbonyl, carboxyl, alkanes, etc. which have been involved on fluoride sorption as well as in the formation of different types of interactions with metals [22]. It has been reported the use of guava seeds as biosorbent for the removal of $\mathrm{Cr}(\mathrm{VI})$ from aqueous solutions with acceptable sorption capacity [23].

Therefore, the main objective of this work was to evaluate removal efficiency of aluminum-modified guava seeds towards fluoride and arsenate from aqueous solutions by obtaining the kinetic and equilibrium parameters of the system, as well as to determine some variable effects over these parameters.

\section{Materials and Methods}

\subsection{Preparation of Biosorbent}

Guava seeds modified with aluminum were used as biosorbent in this study for sorption experiments. Guava seeds (Psidium guajava) were collected from a local traditional candy factory. Guava seeds (GSs) were sieved, and the $1 \mathrm{~mm}$ grain size fraction obtained from this step was washed several times with distilled water to remove impurities. Then, $20 \mathrm{~g}$ of this biosorbent were treated with a $0.5 \mathrm{M} \mathrm{HCl}$ (for $30 \mathrm{~min}$ with $200 \mathrm{~mL}$ at $70^{\circ} \mathrm{C}$ ). The suspension was cooled at room temperature and then neutralized with $1 \mathrm{~N} \mathrm{NaOH}$ solution. Subsequently, the biosorbent was washed with distilled water and dried in an oven at $60{ }^{\circ} \mathrm{C}$ for $24 \mathrm{~h}$ and then placed in a desiccator for further treatment. Later, guava seeds (GSs) were treated with $\mathrm{AlCl}_{3}$ solutions to determine their sorption capacities for $\mathrm{As}(\mathrm{V})$, and the $\mathrm{F}^{-}$Aluminum modification process was carried out as follows: $10 \mathrm{~g}$ of acid treated GSs were put in reflux with $250 \mathrm{~mL}$ of $\mathrm{AlCl}_{3} 0.05 \mathrm{M}$ solution for $3 \mathrm{~h}$. After the solution cooled, the aluminum-modified guava seeds (Al-GSs) were filtered and washed to eliminate excess of aluminum and chloride ions from the biosorbent. Later, Al-GSs were dried at $60^{\circ} \mathrm{C}$ for $4 \mathrm{~h}$, and they were stored in a desiccator to carry out adsorption experiments.

\subsection{Biosorbent Characterization}

Guava seeds modified with aluminum (Al-GSs) were characterized by scanning electron microscopy (SEM), and Fourier transform infrared spectroscopy (FTIR) in order to determine surface 
properties of this material that could be involved in fluoride and arsenate sorption from aqueous solutions. For SEM analysis, GSs and Al-GS samples were covered with copper and analyzed using a scanning electron microscope (JEOL JMS-6400, JEOL Ltd., Peabody, MA, USA) coupled with an EDS microanalysis detector (Bruker XFLASH 4010, Peabody, MA, USA). Fourier transform infrared spectroscopy analyses were performed on the GSs and Al-GS materials both before and after arsenate and fluoride adsorption tests. For this measurement, $0.3 \mathrm{~g}$ of dry $\mathrm{KBr}$ were mixed with $0.02 \mathrm{~g}$ of the dry sample and then compressed with a 3-ton force for $1 \mathrm{~min}$. The samples were analyzed in a Bruker Tensor 27 FTIR spectrophotometer (Bruker Optics Inc., Billerica, MA, USA). The frequency range used was between 200 and $4000 \mathrm{~cm}^{-1}$.

\subsection{Adsorption Kinetic Experiments}

Batch-type tests were carried out to determine the kinetics removal of arsenate and fluoride with Al-GSs, separately. For arsenate removal, $10 \mathrm{~mL}$ aliquots of a $2 \mathrm{mg} / \mathrm{L} \mathrm{Na}_{2} \mathrm{HAsO}_{4} \cdot 7 \mathrm{H}_{2} \mathrm{O}$ solution at $\mathrm{pH} 7$ and $0.1 \mathrm{~g}$ of Al-GSs were placed in centrifuge tubes and shaken for a different duration at $25^{\circ} \mathrm{C}$. Then, the samples were centrifuged and filtered, and the supernatants were analyzed for total arsenic by atomic absorption spectrometry (AAS) by the hydride generation method. For fluoride removal, the same procedure was carried out, but using a $10 \mathrm{mg} / \mathrm{L} \mathrm{NaF}$ solution at $\mathrm{pH} 7$ and $0.1 \mathrm{~g}$ of Al-GSs. The concentration of fluoride ions in the solutions was determined with a selective electrode for fluoride (Hanna HI 98402. Hanna Instruments, Woonsocket, RI, USA). Total ionic strength adjustment buffer solution (TISAB II) was added to all fluoride standards and samples to control the $\mathrm{pH}$ and ionic strength. These methods of arsenic and fluoride measurement were used for aqueous solutions before and after adsorption processes to determine initial and final concentrations of these elements. The quantity of fluoride and arsenic adsorbed by Al-GSs was calculated from the initial concentration by the equation $[24,25]$ :

$$
q=\frac{V\left(C_{0}-C_{e}\right)}{M}
$$

where,

$q=$ measured sorption per unit weight of solid, $(\mathrm{mg} / \mathrm{g})$.

$V=$ volume of solution, $(\mathrm{L})$.

$C_{0}=$ initial concentration of fluoride or arsenic, $(\mathrm{mg} / \mathrm{L})$.

$C_{e}=$ equilibrium concentration of fluoride or arsenic, $(\mathrm{mg} / \mathrm{L})$.

$M=$ dry weight of biosorbent $(\mathrm{g})$.

All adsorption tests were carried out in triplicate to determine the reproducibility of the results, and we considered mean values to calculate adsorption parameters. Adsorption of fluoride or arsenic was not detected on the walls of centrifuge tubes when control experiments were performed.

\subsection{Effect of Adsorbent Dose on Fluoride Removal}

The effect of Al-GSs dosage on the quantity of fluoride adsorbed was studied by adding various amounts $(0.1,0.2,0.3,0.4,0.5,0.6,0.7,0.8,0.9$, and $1.0 \mathrm{~g})$ of Al-GSs into centrifuge tubes containing $10 \mathrm{~mL}$ of a $10 \mathrm{mg} / \mathrm{L} \mathrm{NaF}$ solution without changing the solution $\mathrm{pH}$, at $30^{\circ} \mathrm{C}$. The tubes were placed in a water-bath reciprocal shaker and agitation was provided at $100 \mathrm{rpm}$ until equilibrium as reached. The fluoride concentrations were measured at equilibrium as mentioned above.

\subsection{Effect of $\mathrm{pH}$ on Fluoride Removal}

In order to establish the $\mathrm{pH}$ value at which Al-GSs have a higher fluoride removal and to determine the influence of this parameter on the biosorbent material, batch type adsorption experiments with $\mathrm{Al}-\mathrm{GSs}$ and $10 \mathrm{mg} / \mathrm{L}$ aqueous solutions of sodium fluoride $(\mathrm{NaF})$ were performed. Different $\mathrm{pH}$ values of solutions (between 2 and 9) were established to determine their influence on the adsorption process and set this as a parameter to carry out further experiments. These values were adjusted by adding 
small volumes of $0.1 \mathrm{M}$ solutions of $\mathrm{HCl}$ or $\mathrm{NaOH}$, as appropriate. Adsorption experiments were performed as mentioned above, at different $\mathrm{pH}$ values of the $\mathrm{NaF}$ solution. Solutions were stirred at $100 \mathrm{rpm}$ and $25^{\circ} \mathrm{C}$. Fluoride concentrations were determined as mentioned before.

\subsection{Fluoride and Arsenic Adsorption Isotherms}

Adsorption batch-type experiments were carried out with Al-GS and aqueous solutions of fluoride and $\mathrm{As}(\mathrm{V})$, separately, in order to determine their removal in single pollutant solutions. In centrifuge tubes, $0.6 \mathrm{~g}$ of Al-GS samples were put into contact with $10 \mathrm{~mL}$ of fluoride and arsenic solutions, separately, at concentrations from 10 to $100 \mathrm{mg} / \mathrm{L}$ and from 2 to $45 \mathrm{mg} / \mathrm{L}^{\circ}$ for $\mathrm{F}^{-}$and $\mathrm{As}(\mathrm{V})$, respectively. Centrifuge tubes were placed in a water bath reciprocal agitator at $25{ }^{\circ} \mathrm{C}$ until equilibrium time was reached. Then, the solution was decanted and filtered, and the supernatants were analyzed for total arsenic by AAS and $\mathrm{F}^{-}$analysis by a fluorometer, as required. The experiments were performed in triplicate, as in the previous cases.

\section{Results and Discussion}

\subsection{Biosorbent Characterization}

Guava seed samples were analyzed by SEM in order to determine their morphology, surface properties, and structures before and after their modification with Al. The presence of a heterogeneous surface with different wrinkled, smooth areas, and singular folds can be seen in Figure 1a,b. In Figure 1c,d, the presence of granules and micropores on AL-GS samples are observed. These sites are important because the pores increase solute diffusion and surface area, and thus the fluoride and arsenate sorption capacities. Moreover, an elemental microanalysis (SEM-EDS) and image mapping were performed on the external surface area of a sample of Al-GSs (Figure 2), where the flat smooth surface and the rough part can be observed. Red-colored areas on Al-GS samples indicate that, independently of the morphological surface characteristics, a certain amount of aluminum was adsorbed on the surface of the biosorbent during the modification process (Figure 2b), with an approximate aluminum concentration of $2.7 \mathrm{~g}$ of Al/100 $\mathrm{g}$ of Al-GSs. High or low concentrations of aluminum in some of the zones of the biosorbent surface depended on the diversity and heterogeneity of functional groups present in guava seed structure [26]. Arsenic and fluoride were also analyzed by SEM-EDS, and the results showed an approximate punctual concentration of arsenic of $0.54 \mathrm{~g}$ of As /100 g of AL-GS (Figure 2c), but fluoride was not detected due to a low concentration of analyzed samples. These results suggest that aluminum-modified parts of Al-GS surface can adsorb As(V) ions, as well as some unmodified parts of the same material.

\subsection{Fourier Transform Infrared Spectroscopy}

Figure 3 shows the FTIR results of unmodified guava seeds (GSs) and aluminum-modified guava seeds (Al-GSs). Different functional groups, like C-O-C, $-\mathrm{C}=\mathrm{O},-\mathrm{COOH},-\mathrm{NH},-\mathrm{CH}_{2}$, and $-\mathrm{OH}$ are present on GSs' surface (Figure 3a). These groups are characteristic of lignocellulosic materials. Absorption bands from $1700 \mathrm{~cm}^{-1}$ to $1200 \mathrm{~cm}^{-1}$ were attributed to carbonyl groups $(C=O)$ of aldehyde and ketone and to C-O group [27]. Comparing GS and Al-GS spectra (Figure 3a), variations on absorption bands can be observed at $3402.3 \mathrm{~cm}^{-1}$, corresponding to $-\mathrm{OH}$ groups which can be attributed to the fact that intermolecular hydrogen bonds can exist because of hydroxyl groups adjacent to glucose units in the cellulose molecule, which is one of the main components of GS biosorbent [26]. The changes in vibrational frequencies around $3030-2385 \mathrm{~cm}^{-1}$, corresponding to amino and aldehyde groups indicate the attachment of $\mathrm{Al}$ metal ions to these functional groups on the GS surface [27]. Moreover, new peaks are observed in SG-Al spectra after modification with $\mathrm{Al}$, particularly those at $1445 \mathrm{~cm}^{-1}$ and $1546 \mathrm{~cm}^{-1}$ that have been associated with the presence of surface hydroxide groups ( $\left.\mathrm{AlOH}\right)$ [28] or to Al-O bending. Furthermore, a shift on the absorption band at $1751 \mathrm{~cm}^{-1}$ corresponding to $\mathrm{C}=\mathrm{O}$ 
group was observed (Figure 3a), which has been attributed to the formation of coordination bonds between this group (O atoms) and the $\mathrm{Al}$ ions [29].
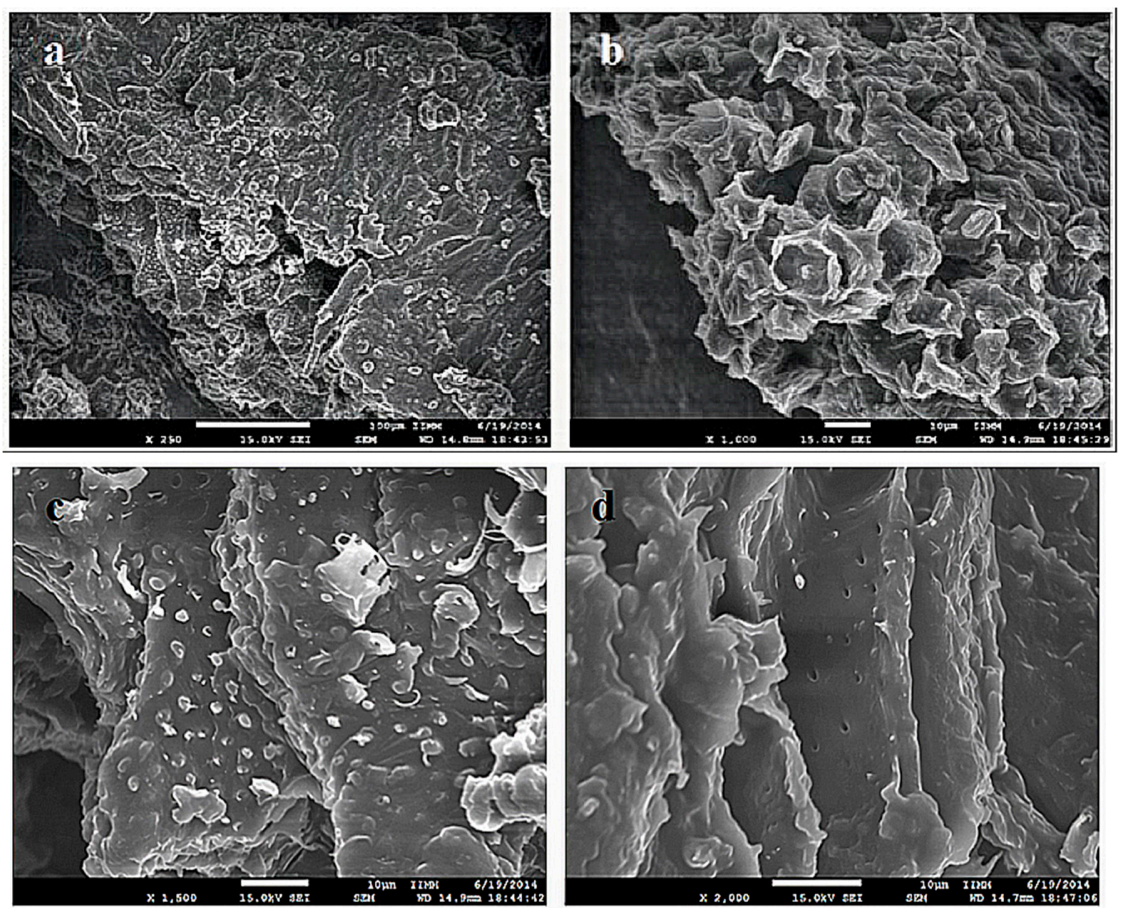

Figure 1. SEM analyses of Al-GS samples: (a) Al-GS sample observed at 250×; (b) wrinkled zone observed at $1000 \times$; (c) granules observed at $1500 \times$ on Al-GS sample; (d) micropores observed at $2000 \times$.

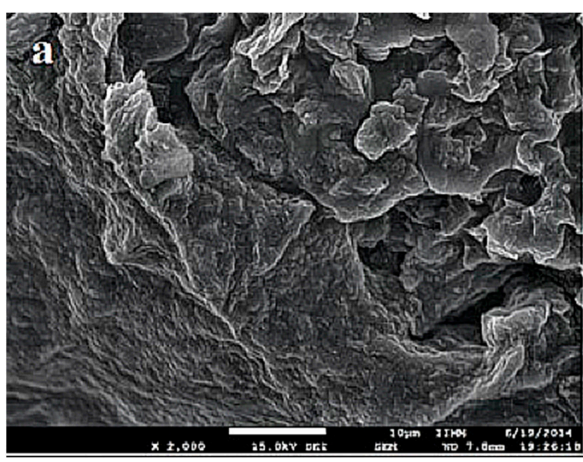

(a)

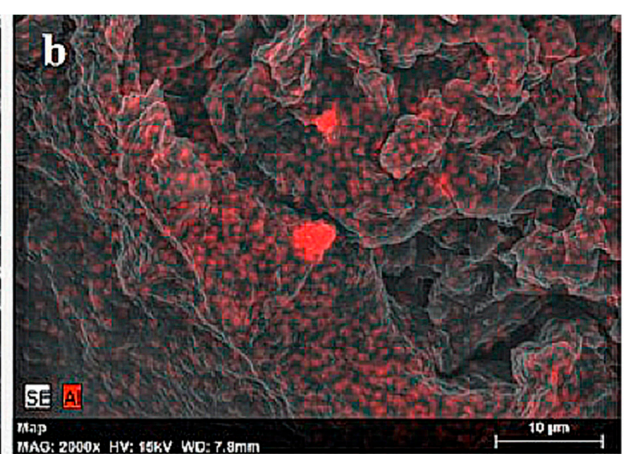

(b)

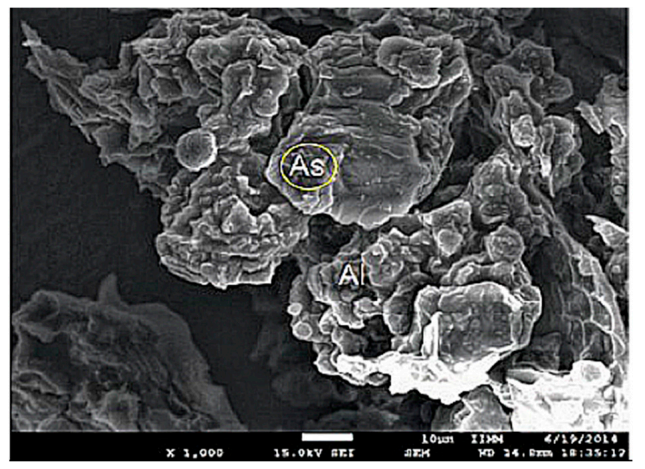

(c)

Figure 2. SEM-EDS analyses of Al-GS samples: (a) Al-GS sample observed at 2000×; (b) SEM-EDS mapping of Al-GS observed at $1000 \times$; (c) Al-GS after fluoride and arsenate sorption observed at $1000 \times$. 


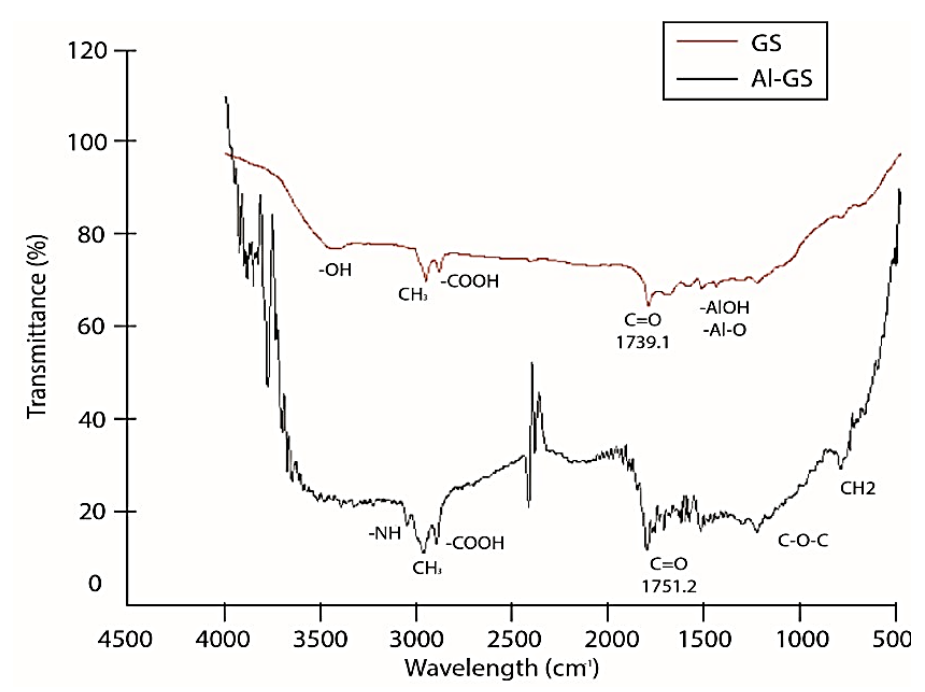

(a)

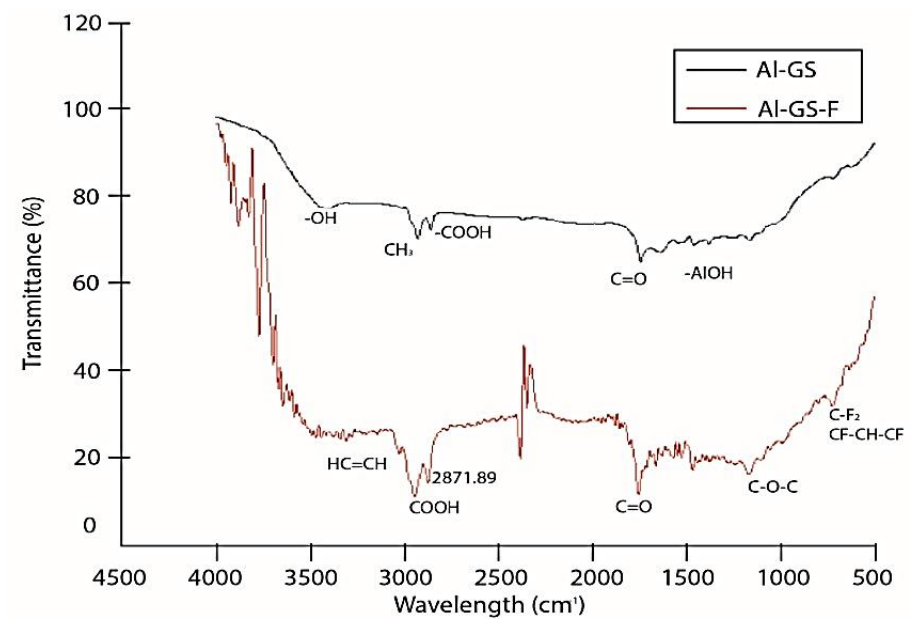

(b)

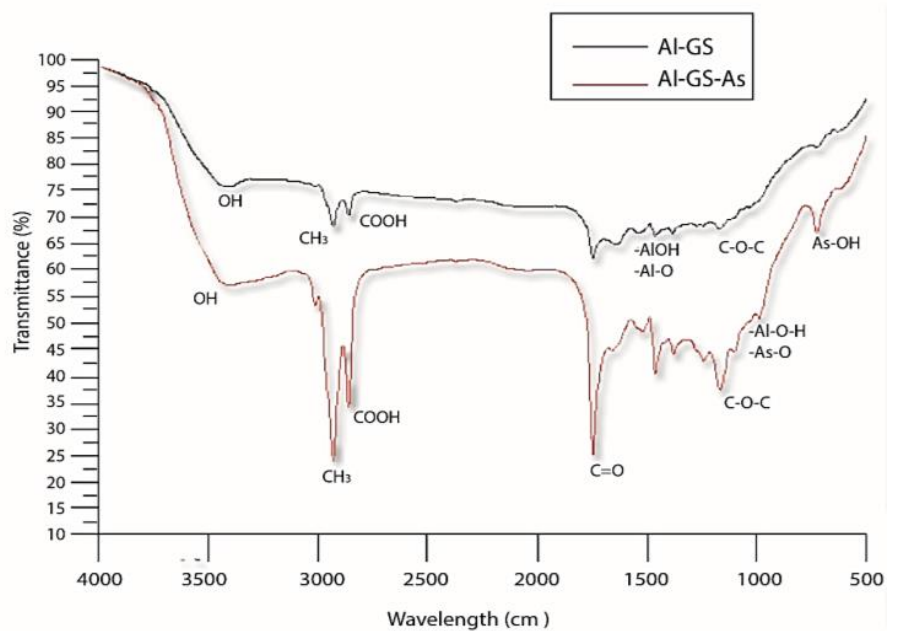

(c)

Figure 3. FTIR spectra: (a) GS and Al-GS samples; (b) GS and Al-GS-F samples; (c) Al-GS and Al-GS-As samples. 
According to FTIR spectra observed in Figure 3b, it can be noticed that the functional groups associated with fluoride ions removal by Al-GS are: hydroxyl, carbonyl, and methoxy methyl ether. The $\mathrm{OH}$ groups' disappearance was observed at $3402 \mathrm{~cm}^{-1}$. This can be attributed to the fact that fluoride and hydroxyl ions have similar dimensions and they can exchange each other to form Al-F complexes due to the interaction of $\mathrm{F}^{-}$ions with aluminum ions on the surface of the material, without breaking the Al-O-Al bonds. [26,30]. This could explain the changes in $\mathrm{pH}$ values of fluoride solutions before and after adsorption. Moreover, the bands that appeared in the range from 400 to $700 \mathrm{~cm}^{-1}$ in the Al-GS-F spectrum have been attributed to the vibration of the aluminum-fluoride bonds [26], as well as the band present at $880 \mathrm{~cm}^{-1}$ [31]. Besides, a band at $761.3 \mathrm{~cm}^{-1}$ can be observed after fluoride adsorption, corresponding to bending motion of $\mathrm{CF}_{2}$ and skeletal bending of $\mathrm{CF}-\mathrm{CH}-\mathrm{CF}$ [32].

A FTIR analysis for the biosorption of $\mathrm{As}(\mathrm{V})$ onto Al-GS was also carried out. It can be observed (Figure 3c) that the band at $738 \mathrm{~cm}^{-1}$ corresponds to the symmetric stretch of As-OH bond [33,34]. Besides, symmetric and asymmetric stretching modes of the As-O bonds in the FTIR spectrum can be observed at 878 and $907 \mathrm{~cm}^{-1}$, respectively [33]. Moreover, the bands at $844-855 \mathrm{~cm}^{-1}$ are assigned to the As-O vibration of an inner-sphere Al-O-As complex $[33,35,36]$. These results indicate that the mechanisms involved on $\mathrm{As}(\mathrm{V})$ sorption onto Al-GS biosorbent are those related to the interactions between arsenate ion and aluminum on the surface of the guava seeds, along with the active sites on the lignocellulosic structure of GSs.

\subsection{Arsenate and Fluoride Biosorption Kinetics}

Adsorption kinetics is the measure of the adsorption uptake with respect to time and then the time at which the process reaches equilibrium. Figures 4-6 show the results obtained in the kinetics experiments using Al-GSs for the removal of fluorides, arsenic, and the simultaneous removal of these two compounds, respectively.

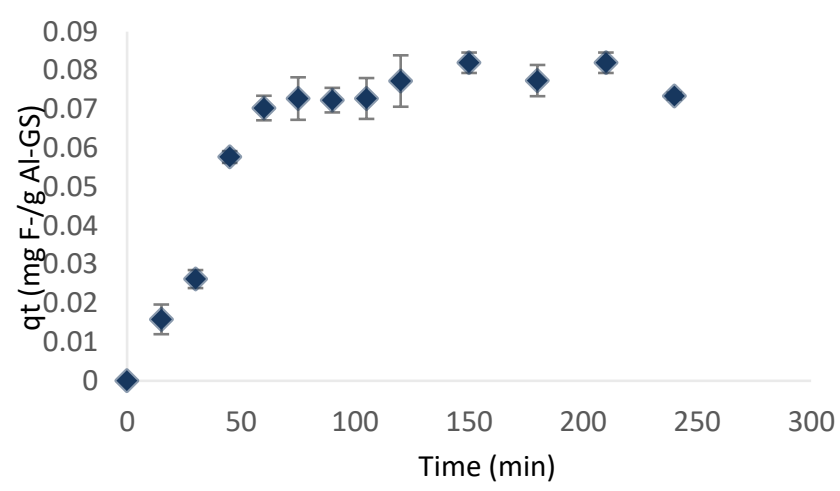

Figure 4. Adsorption capacity of fluorides (qt) as a function of contact time.

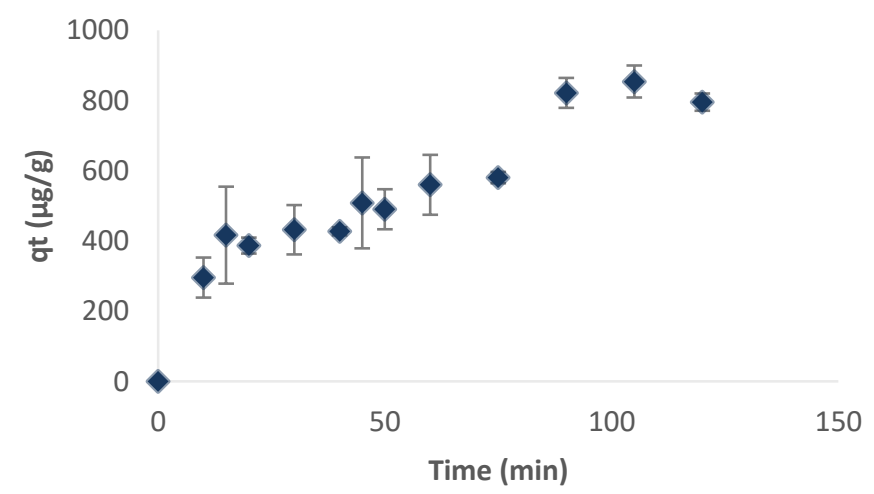

Figure 5. Adsorption capacity (qt) of arsenate as a function of contact time. 


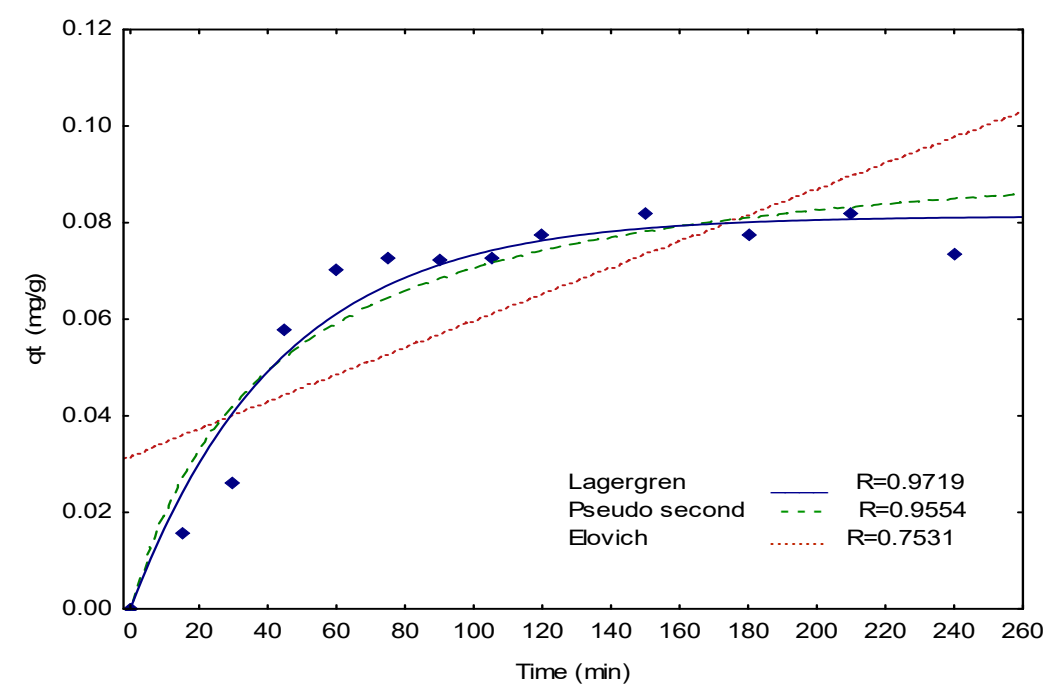

Figure 6. Adsorption of fluoride by Al-GSs as a function of time fitted to the empirical kinetic models.

According to Figure 4, most of the fluoride biosorption was attained in the first 60 min of contact, where it reaches a removal of approximately $40 \%$ with an adsorbent dose of $10 \mathrm{~g} / \mathrm{L}$. From this time, fluoride biosorption rate was slower, until no significant changes were observed in the concentration of $\mathrm{F}^{-}$in the adsorbent. Therefore, the equilibrium point was established at $150 \mathrm{~min}$. This behavior could be attributed to the high concentration gradient between the solution and the Al-GSs, so the biosorption rate was fast at the initial stages of the process, as well as to the large availability of sorption sites on the beginning of biosorption. As the process continues, the available adsorption sites and the concentration gradient began to decrease, and a slower sorption rate was observed [37]. The capacity of Al-GSs for fluoride removal at equilibrium was $0.08 \mathrm{mg} / \mathrm{g}$. Kinetics experiments using unmodified guava seeds as biosorbent showed low fluoride adsorption at these experimental conditions. These results indicate that aluminum modification improved fluoride removal from aqueous solutions in single systems.

Concerning the arsenate adsorption kinetics with Al-GSs, a similar behavior was observed since a rapid biosorption was noticed in the first $90 \mathrm{~min}$, reaching approximately $60 \%$ removal. From this time, equilibrium of the system was reached and no significant changes in arsenate biosorbent concentration were observed; as a result, this time was chosen for the further biosorption experiments. An equilibrium adsorption capacity of $0.85 \mathrm{mg} / \mathrm{g}$ was reached. It was observed that the kinetics of removal of As is slightly faster than the kinetics of removal of $\mathrm{F}^{-}$.

Adsorption kinetic data were fitted to different empirical models by nonlinear regression analysis, using the STATISTICA 7.0 software (StatSoft, Inc., Tulsa, OK, USA, 2002). These empirical kinetic models have been used for this type of adsorption system.

The pseudo first-order model, or Lagergren equation, is expressed as follows [38]:

$$
q_{t}=q_{e}\left(1-e^{-k_{L} t}\right)
$$

where,

$K_{L}=$ Lagergren rate constant, $\left(\mathrm{min}^{-1}\right)$.

$q_{t}=$ quantity of ion adsorbed at any given time $t,(\mathrm{mg} / \mathrm{g})$.

$q_{e}=$ quantity of ion adsorbed at equilibrium, $(\mathrm{mg} / \mathrm{g})$.

The pseudo second-order model, proposed by Ho et al. [39] can be expressed on its nonlinear form by the following equation:

$$
q_{t}=\frac{K_{2} q_{e}^{2} t}{1+K_{2} q_{e} t}
$$

where, 
$K_{2}=$ pseudo-second-order rate constant, $(\mathrm{g} / \mathrm{mg} \mathrm{min})$.

$q_{t}=$ quantity of ion adsorbed at any given time $t,(\mathrm{mg} / \mathrm{g})$.

$q_{e}=$ quantity of ion adsorbed at equilibrium, $(\mathrm{mg} / \mathrm{g})$.

The pseudo-second-order model is based on the supposition that the rate-limiting step may be chemisorption involving valence forces through sharing or exchange of electrons between adsorbent and adsorbate [39].

The Elovich equation has been usually reported for chemisorption of gases on solids. This equation can be expressed as follows [40]:

$$
q_{t}=\frac{1}{b} \ln (1+a b t)
$$

where,

$q_{t}=$ adsorbate concentration at any time, $t$, per weight of adsorbent, $(\mathrm{mg} / \mathrm{g})$.

$a=$ Elovich constant related to the initial adsorption rate, $(\mathrm{mg} / \mathrm{g} \mathrm{min})$.

$b=$ Elovich constant related to the desorption rate, $(\mathrm{g} / \mathrm{mg})$.

Figures 6 and 7 show the fitted plots to the kinetic models. Tables 1 and 2 show the model's parameters and correlation coefficients for fluoride and arsenate adsorption onto Al-GSs, respectively. The model that best describes the adsorption experimental data is the pseudo-first-order model, or Lagergren equation since the correlation coefficients for fluoride and arsenate removal are higher than for the other two models. However, in the case of fluoride biosorption, pseudo second-order model shows a good fit to experimental data $\left(R^{2}=0.9127\right)$; thus it can describe fluoride sorption. For the case of arsenate removal, the Lagergren model describes well biosorption kinetic data, but pseudo-second-order and Elovich equations are not suitable to describe arsenate sorption on Al-GS.

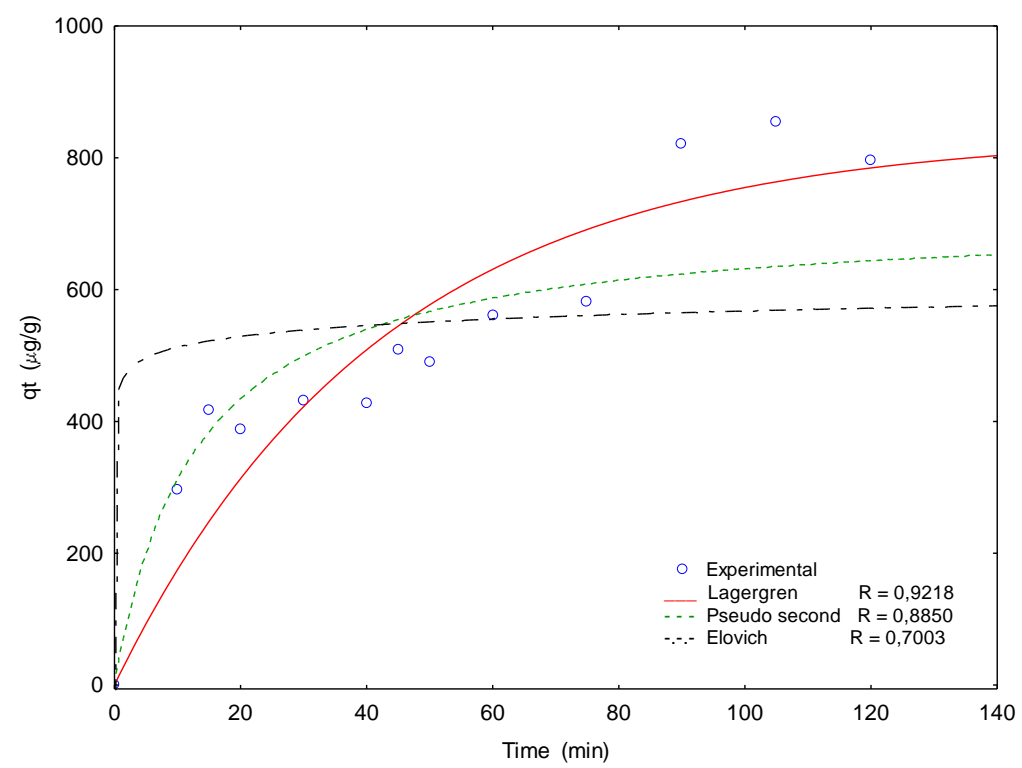

Figure 7. Adsorption of arsenate by Al-GSs as a function of time fitted to the empirical kinetic models.

Table 1. Kinetic models parameters for fluoride adsorption onto Al-GSs.

\begin{tabular}{ccc}
\hline Model & Kinetic Parameters & Correlation Coefficient (R) \\
\hline pseudo-first-order (Lagergren) & $\begin{array}{c}\mathrm{K}_{\mathrm{L}}\left(\mathrm{min}^{-1}\right)=0.0231 \\
\mathrm{q}_{\mathrm{e}}(\mathrm{mg} / \mathrm{g})=0.0813\end{array}$ & 0.9719 \\
\hline pseudo-second-order & $\begin{array}{c}\mathrm{K}_{2}(\mathrm{~g} / \mathrm{mg} \mathrm{min})=0.0993 \\
\mathrm{q}_{\mathrm{e}}(\mathrm{mg} / \mathrm{g})=0.0813\end{array}$ & 0.9554 \\
\hline Elovich & $\begin{array}{c}\mathrm{a}(\mathrm{mg} / \mathrm{g} \min )=0.0003 \\
\mathrm{~b}(\mathrm{~g} / \mathrm{mg})=1.0162\end{array}$ & 0.7531 \\
\hline
\end{tabular}


Table 2. Kinetic parameters for arsenate biosorption by Al-GSs.

\begin{tabular}{ccc}
\hline Model & Kinetic Parameters & Correlation Coefficient (R) \\
\hline Lagergren & $\begin{array}{r}\mathrm{K}_{\mathrm{L}}\left(\mathrm{min}^{-1}\right)=0.0235 \\
\mathrm{q}_{\mathrm{e}}(\mathrm{mg} / \mathrm{g})=834.26\end{array}$ & 0.9218 \\
\hline pseudo-second-order & $\begin{array}{r}\mathrm{K}_{2}(\mathrm{~g} / \mathrm{mg} \mathrm{min})=5 \times 10^{-5} \\
\mathrm{q}_{\mathrm{e}}(\mathrm{mg} / \mathrm{g})=712.5\end{array}$ & 0.8850 \\
\hline Elovich & $\begin{array}{r}\mathrm{a}(\mathrm{mg} / \mathrm{g} \mathrm{min})=5.3 \times 10^{-9} \\
\mathrm{~b}(\mathrm{~g} / \mathrm{mg})=0.0420\end{array}$ & 0.7003 \\
\hline
\end{tabular}

\subsection{Effect of Adsorbent Dose on Fluoride Removal}

The effect of the biosorbent dose is an important parameter because it directly influences the removal efficiency of the system. In Figure 8 it can be seen that the percentage of fluoride removal rises as the biosorbent dose increases because of the increase in the number of active sites at high adsorbent material dosages until a dose of $70 \mathrm{~g} / \mathrm{L}$ is reached. From this point, the removal of fluorides begins to decrease and stabilize, which can be attributed to a higher quantity of active sites not occupied by the $\mathrm{F}^{-}$ions, both on the surface and in the pores of the biosorbent and also to biosorbent crowding [26,41]. Therefore, the optimal dose used for the further fluoride biosorption experiments was $70 \mathrm{~g} / \mathrm{L}$. A similar behavior was observed and reported previously [42] for the case of arsenate removal by AL-GSs at different dosages where the optimal biosorbent dose found was $60 \mathrm{~g} / \mathrm{L}$.

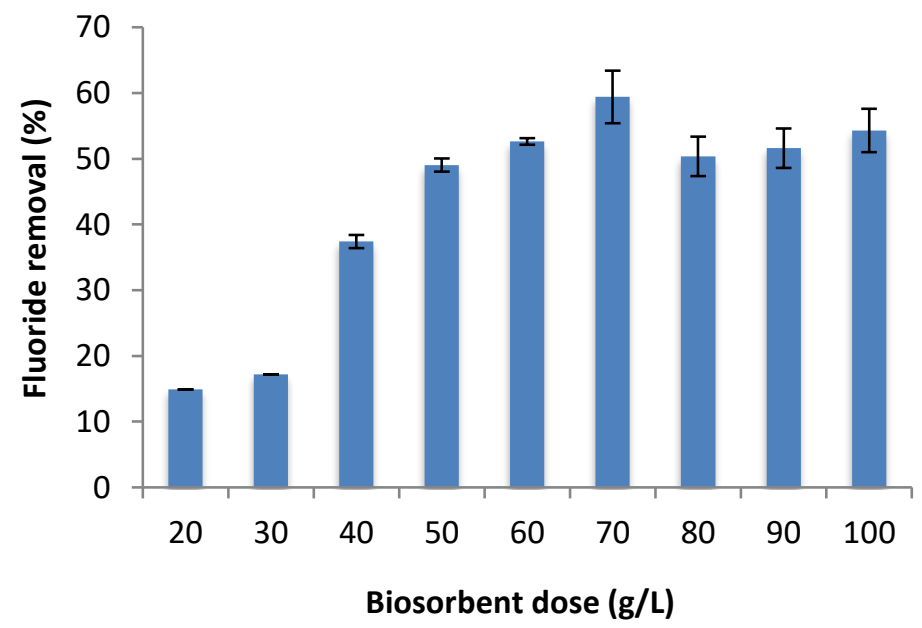

Figure 8. Adsorbent dose effect on the adsorption of fluoride by Al-GSs.

\subsection{Effect of $\mathrm{pH}$ on Fluoride Removal}

Since changing $\mathrm{pH}$ of the solution in sorption processes can modify the surface charge of an adsorbent and this change directly affects ionization and chemical speciation of the adsorbate, then $\mathrm{pH}$ is an important parameter in these types of processes. Figure 9 shows the variation in fluoride sorption capacity at various $\mathrm{pH}$ values using Al-GSs as an adsorbent. The removal of $\mathrm{F}^{-}$ions was the highest in acidic conditions ( $\mathrm{pH} 2$ and 3), but this increase could be explained by HF formation at these $\mathrm{pH}$ values since $\mathrm{pKa}$ value of $\mathrm{HF}$ is 3.17 . At $\mathrm{pH} 4$ and 5 , where the $\mathrm{F}^{-}$species begins to predominate on aqueous solutions, a significant decrease in fluoride sorption is observed and this could be attributed to aluminum modification of the biosorbent, since the point of zero charge $\left(\mathrm{pH}_{\mathrm{PZC}}\right)$ for this type of modified adsorbents has been reported approximately at a $\mathrm{pH}$ value of 4 to 5 . This is also in agreement with the $\mathrm{pH}_{\mathrm{PZC}}=5$ reported for $\mathrm{Al}(\mathrm{OH})_{3}$ [28], which is the proposed form of the aluminum present on the surface of this biosorbent. The highest removal of $\mathrm{F}^{-}$ions can be observed at $\mathrm{pH} 6$ where ligand exchange can be the main sorption mechanism. At higher $\mathrm{pH}$ values the removal decreases significantly. This can be explained by different reasons: less availability of sites for fluoride electrostatic adsorption, 
or competition between fluoride ions with a high concentration of hydroxyl ions for the positively charged sites on the Al-GS surface [43]. Fluoride removal increased at $\mathrm{pH} 8$ compared to $\mathrm{pH} 7$. This behavior could be explained since aluminate ion, $\mathrm{Al}(\mathrm{OH})_{4}{ }^{-}$, is formed at $\mathrm{pH}$ above 8 due to the dissolution of the aluminum present on the surface of the adsorbent [44]. This aluminate ion may compete with $\mathrm{F}^{-}$at $\mathrm{pH}$ values around 7 , but at $\mathrm{pH}$ values near 8 the $\mathrm{Al}(\mathrm{OH})_{2} \mathrm{~F}_{2}{ }^{-}$complex could be formed in solution $[45,46]$; consequently, a decrease in the concentration of free fluoride ions in solution occurred with a corresponding increase in the percentage of removal.

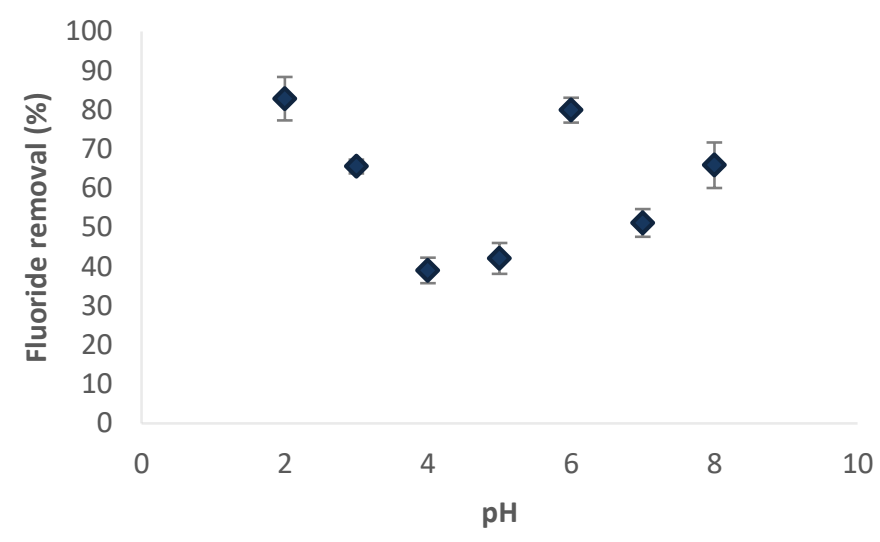

Figure 9. Effect of $\mathrm{pH}$ on the removal of fluoride by Al-GSs.

\subsection{Fluoride and Arsenic Adsorption Isotherms}

Quantitative analysis of adsorbate-adsorbent interactions is important for the evaluation of the adsorbent. Adsorption isotherms of fluoride and arsenate onto Al-GSs are presented in Figures 10 and 11, respectively. Experimental data were fitted to isotherm models of Langmuir, Freundlich, and Langmuir-Freundlich (L-F) by non-linear regression analyses [26]. Results show that fluoride adsorption isotherm can be well described by the Langmuir and Langmuir-Freundlich (L-F) models ( $R$ $=0.9885$ ). However, the L-F model indicates sorption on heterogeneous surfaces implying different sorption energies of the adsorption sites; therefore, this model can be used for the description of fluoride equilibrium data. This is in agreement with the proposed mechanisms for fluoride removal described above where different types of sorption sites are responsible for the $\mathrm{F}^{-}$removal. A maximum adsorption capacity of $0.3445 \mathrm{mg}$ of $\mathrm{F}^{-} / \mathrm{g}$ of Al-GS was determined. Supernatants were also analyzed for $\mathrm{Al}$ leaching after adsorption, by AAS with a nitrous oxide-acetylene flame, but $\mathrm{Al}$ concentrations were below the detection limit $(0.4 \mathrm{mg} / \mathrm{L})$.

Arsenate adsorption onto Al-GS (Figure 11) showed a slightly different behavior compared to fluoride sorption isotherm. In this case, Freundlich and L-F models fitted well arsenate sorption equilibrium data at these experimental conditions. A relatively high sorption capacity was determined at $4 \mathrm{mg}$ of $\mathrm{As}(\mathrm{V}) / \mathrm{g}$ of $\mathrm{Al}-\mathrm{GS}$. A similar sorption behavior was reported for the arsenate removal by Al-Based nanoparticle impregnated sawdust [47]. Table 3 shows a comparison of fluoride and arsenate sorption capacities for different adsorbents. Guava seed surface without aluminum modification showed a low fluoride adsorption capacity, but a significant arsenate sorption capacity; thus, the biosorbent was modified to enhance fluoride adsorption capacity and to use this material in cases where simultaneous removal of both ions is required. This aluminum-modified adsorbent has the advantage over aluminum-based coagulants of not producing sludge and also a better recovery of this element. Adsorption capacities around $1 \mathrm{mg} / \mathrm{g}$ and $11 \mathrm{mg} / \mathrm{g}$ for fluorides and arsenates, respectively, have been reported using activated alumina as adsorbent [48]. By comparing these adsorption capacities with those obtained in this work, Al-GS can be considered as a relatively efficient and low-cost alternative for the adsorption of these ions from water. 


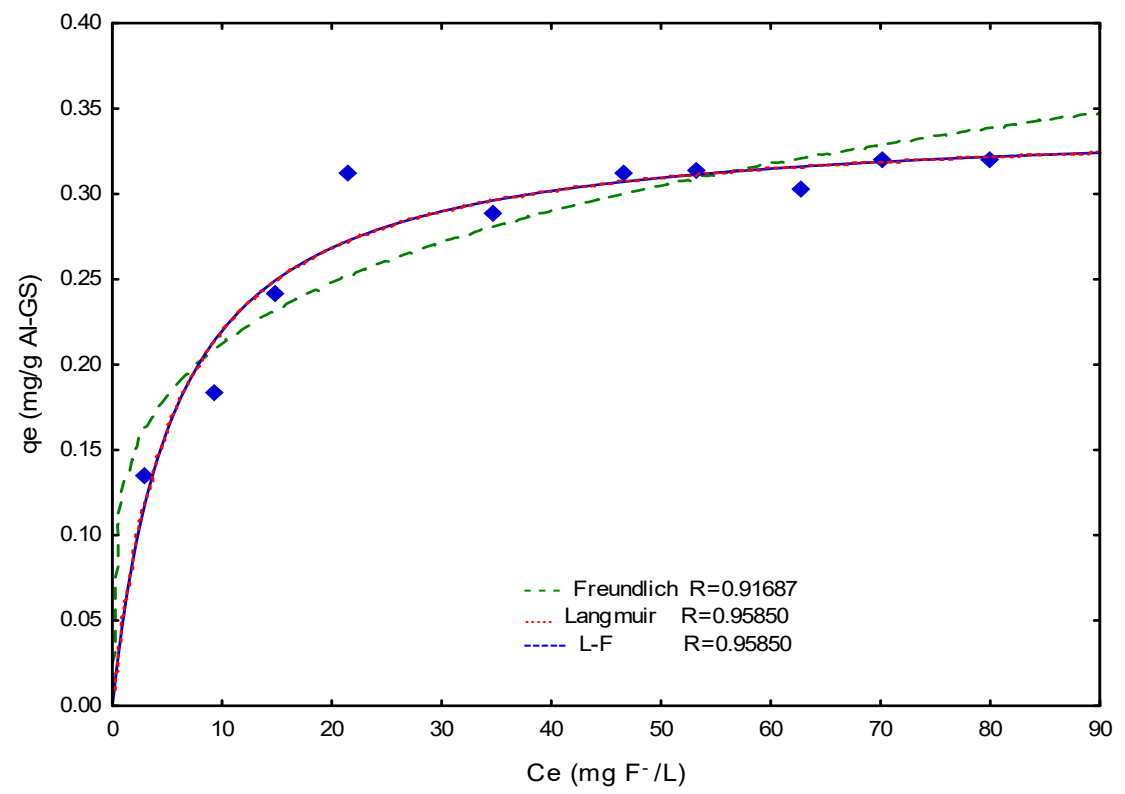

Figure 10. Adsorption isotherm of fluoride on Al-GS, at $25^{\circ} \mathrm{C}$ and $\mathrm{pH}$ 6, fitted to isotherm models.

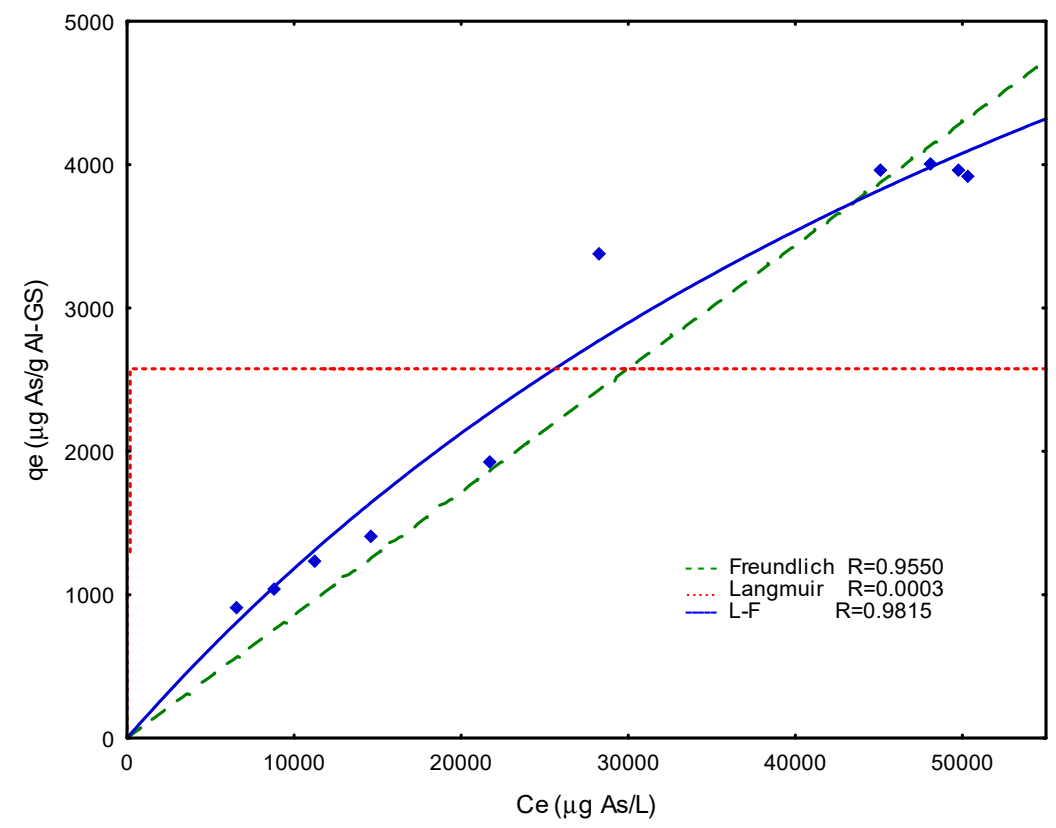

Figure 11. Adsorption isotherm of arsenate on Al-GS, at $25^{\circ} \mathrm{C}$ and $\mathrm{pH}$ 6, fitted to isotherm models.

Table 3. Maximum adsorption capacities $\left(\mathrm{q}_{\max }\right)$ of fluoride and arsenate of Al-GSs and other adsorbents.

\begin{tabular}{|c|c|c|c|c|}
\hline Adsorbent & Adsorbate & $\mathrm{q}_{\max }(\mathrm{mg} / \mathrm{g})$ & Solution $\mathrm{pH}$ & Reference \\
\hline Al-GS & As $(V)$ & 4 & 6 & This work \\
\hline Fe-Al modified zeolite & As $(\mathrm{V})$ & 3.31 & 2 & [49] \\
\hline Fe-Al modified pozzolan & As $(\mathrm{V})$ & 3.35 & 2 & [49] \\
\hline Stem of Tecomella undulata & As $(V)$ & 0.159 & 7 & {$[50]$} \\
\hline Watermelon rind & $\mathrm{As}(\mathrm{V})$ & 3.29 & 5.3 & [51] \\
\hline Aluminum-enriched biochar from Tetra Paks & As $(V)$ & 33.2 & 3 & [52] \\
\hline Al-GS & $\mathrm{F}^{-}$ & 0.3445 & 6 & This work \\
\hline Fe-Al modified zeolite & $\mathrm{F}^{-}$ & 0.866 & 2 & [49] \\
\hline Fe-Al modified pozzolan & $\mathrm{F}^{-}$ & 0.834 & 2 & [49] \\
\hline Stem of Tecomella undulata & $\mathrm{F}^{-}$ & 6.16 & 7 & [50] \\
\hline Active carbon of Ficus racemosa & $\mathrm{F}^{-}$ & 1.65 & 7 & [53] \\
\hline Sweet lemon peel powder & $\mathrm{F}^{-}$ & 0.744 & 4 & [54] \\
\hline
\end{tabular}




\section{Conclusions}

The modification of the surface of guava seeds with aluminum plays an important role in the adsorption mechanisms, since the arsenate and fluoride ions form complexes with aluminum on the surface of the adsorbent, as well as forming them with other functional groups present in the material.

The removal of arsenate is slightly faster than that of fluoride since time to reach sorption equilibrium was lower for $\mathrm{As}(\mathrm{V})$ removal $(90 \mathrm{~min})$ than for $\mathrm{F}^{-}$removal $(150 \mathrm{~min})$. Fluoride adsorption is significantly affected by $\mathrm{pH}$, particularly in highly acidic and alkaline values. The model L-F was the one that best describes the data of adsorption equilibrium by Al-GSs in both cases, reaching sorption capacities for $\mathrm{As}(\mathrm{V})$ of $4 \mathrm{mg} / \mathrm{g}$ and for $\mathrm{F}^{-}$of $0.3445 \mathrm{mg} / \mathrm{g}$. The FTIR results indicate that both systems present chemisorption on a heterogeneous surface. The Al-GSs can be considered as a good adsorbent for arsenate and fluoride removal from aqueous solutions.

Author Contributions: S.R.-V. and R.C.-M. conceived and designed experiments; S.R.-V. performed the experiments; R.A.-C.-V. and R.H.-A. contributed with fluoride and arsenic determination and analysis of data and analyzed characterization of the material. R.C.-M. wrote the paper.

Funding: Project SENER-CONACYT 268074, GEMex PT 4.3 and project CIC-UMSNH-2018.

Acknowledgments: The authors would like to acknowledge the financial support provided by Coordinación de la Investigación Científica-UMSNH, project CIC-UMSNH-2018, and are thankful to S.A. Valencia-Leal for the technical and analytical support.

Conflicts of Interest: The authors declare no conflict of interest.

\section{References}

1. Barathi, M.; Kumar, A.; Santhana, K.; Rajesh, N. Efficacy of novel Al-Zr impregnated cellulose adsorbent prepared using microwave irradiation for the facile defluoridation of water. J. Environ. Chem. Eng. 2013, 1, 1325-1335. [CrossRef]

2. Bechir, A.; Sirbu, R.; Bechir, E.S.; Pacurar, M.; Ghergic, D.L.; Arghir, O.C. Dental fluorosis as a result of cumulated exposure. J. Environ. Prot. Ecol. 2012, 13, 2161-2166.

3. World Health Organization (WHO). Guidelines for Drinking-Water Quality, 3rd ed.; WHO: Geneva, Switzerland, 2008.

4. Jiménez-Becerril, J.M.; Solache-Ríos, M.; García-Sosa, I. Fluoride removal from aqueous solutions by boehmite. Water Air Soil Pollut. 2012, 223, 1073-1078. [CrossRef]

5. Sujana, M.G.; Pradhan, H.K.; Anand, S. Studies on sorption of some geomaterials for fluoride removal from aqueous solutions. J. Hazard. Mater. 2009, 161, 120-125. [CrossRef] [PubMed]

6. Teutli-Sequeira, A.; Solache-Ríos, M.; Balderas-Hernández, P. Modification effects of hematite with aluminum hydroxide on the removal of fluoride ion from water. Water Air Soil Pollut. 2012, 223, 319-327. [CrossRef]

7. Teutli-Sequeira, A.; Solache-Ríos, M.; Martínez-Miranda, V.; Linares-Hernández, I. Comparison of aluminum modified natural materials in the removal of fluoride ions. J. Colloid Interface Sci. 2014, 418, $254-260$. [CrossRef] [PubMed]

8. Sánchez-Sánchez, H.A.; Cortés-Martínez, R.; Alfaro-Cuevas-Villanueva, R. Fluoride removal from aqueous solutions by mechanically modified guava seeds. Int. J. Sci. Basic Appl. Res. 2013, 11, 159-172.

9. Dupont, L.; Jolly, G.; Aplincourt, M. Arsenic adsorption on lignocellulosic substrate loaded with ferric ion. Environ. Chem. Lett. 2007, 5, 125-129. [CrossRef]

10. Mueller, B.; Hug, S.J. Climatic variations and de-coupling between arsenic and iron in arsenic contaminated ground water in the lowlands of Nepal. Chemosphere 2018, 210, 347-358. [CrossRef] [PubMed]

11. Smedley, P.L.; Kinniburgh, D.G. A review of the source, behaviour and distribution of arsenic in natural waters. Appl. Geochem. 2002, 17, 517-568. [CrossRef]

12. Jing, C.; Cui, J.; Huang, Y.; Li, A. Fabrication, characterization, and application of a composite adsorbent for simultaneous removal of arsenic and fluoride. ACS Appl. Mater. Interfaces 2012, 4, 714-720. [CrossRef] [PubMed]

13. Liu, R.; Gong, W.; Lan, H.; Yang, T.; Liu, H.; Qu, J. Simultaneous removal of arsenate and fluoride by iron and aluminum binary oxide: Competitive adsorption effects. Sep. Purif. Technol. 2012, 92, 100-105. [CrossRef] 
14. Monser, L.; Adhoum, N. Modified activated carbon for the removal of copper, zinc, chromium and cyanide from wastewater. Sep. Purif. Technol. 2002, 26, 137-146. [CrossRef]

15. Diaz-Nava, C.; Olguin, M.T.; Solache-Ríos, M. Water defluoridation by Mexican heulandite-clinoptilolite. Sep. Sci. Technol. 2002, 37, 3109-3128. [CrossRef]

16. Jiménez-Núñez, M.L.; Olguín, M.T.; Solache-Ríos, M. Fluoride removal from aqueous solutions by magnesium, nickel, and cobalt calcined hydrotalcite-like compounds. Sep. Sci. Technol. 2007, 42, 3623-3639. [CrossRef]

17. Ghorai, S.; Pant, K.K. Equilibrium, kinetics and breakthrough studies for adsorption of fluoride on activated alumina. Sep. Purif. Technol. 2005, 42, 265-271. [CrossRef]

18. Amin, F.; Talpur, F.N.; Balouch, A.; Surhio, M.A.; Bhutto, M.A. Biosorption of fluoride from aqueous solution by white-rot fungus Pleurotus eryngii ATCC 90888. Environ. Nanotechnol. Monit. Manag. 2015, 3, 30-37. [CrossRef]

19. Tang, Y.; Wang, J.; Gao, N. Characteristics and model studies for fluoride and arsenic adsorption on goethite. J. Environ. Sci. 2010, 22, 1689-1694. [CrossRef]

20. Tian, Y.; Wu, M.; Liu, R.; Wang, D.; Lin, X.; Liu, W.; Ma, L.; Li, Y.; Huang, Y. Modified native cellulose fibers-A novel efficient adsorbent for both fluoride and arsenic. J. Hazard. Mater. 2011, 185, 93-100. [CrossRef] [PubMed]

21. Crini, G.; Lichtfouse, E.; Wilson, L.D.; Morin-Crini, N. Conventional and non-conventional adsorbents for wastewater treatment. Environ. Chem. Lett. 2018. [CrossRef]

22. Cai, H.; Chen, G.; Peng, C.; Xu, L.; Zhu, X.; Zhang, Z.; Dong, Y.; Shang, G.; Ke, F.; Gao, H.; et al. Removal of fluoride from drinking water using tea waste loaded with $\mathrm{Al} / \mathrm{Fe}$ oxides: A novel, safe and efficient biosorbent. Appl. Surf. Sci. 2015, 328, 34-44. [CrossRef]

23. Abdelwahab, O.; El Sikaily, A.; Khaled, A.; ElNemr, A. Mass-transfer processes of chromium (VI) adsorption onto guava seeds. Chem. Ecol. 2007, 23, 73-85. [CrossRef]

24. Mahmoud, A.E.D.; Stolle, A.; Stelter, M. Sustainable synthesis of high-surface-area graphite oxide via dry ball milling. ACS Sustain. Chem. Eng. 2018, 6, 6358-6369. [CrossRef]

25. Mahmoud, A.E.D.; Fawzy, M.; Radwan, A. Optimization of Cadmium $\left(\mathrm{CD}^{2+}\right)$ removal from aqueous solutions by novel biosorbent. Int. J. Phytorem. 2016, 18, 619-625. [CrossRef] [PubMed]

26. Vázquez-Guerrero, A.; Alfaro-Cuevas-Villanueva, R.; Rutiaga-Quiñones, J.G.; Cortés-Martínez, R. Fluoride removal by aluminum-modified pine sawdust: Effect of competitive ions. Ecol. Eng. 2016, 94, 365-379. [CrossRef]

27. Nadeem, R.; Manzoor, Q.; Iqbal, M.; Nisar, J. Biosorption of Pb (II) onto immobilized and native Mangifera indica waste biomass. J. Ind. Eng. Chem. 2016, 35, 185-194. [CrossRef]

28. Guaya, D.; Valderrama, C.; Farran, A.; Armijos, C.; Cortina, J.L. Simultaneous phosphate and ammonium removal from aqueous solution by a hydrated aluminum oxide modified natural zeolite. Chem. Eng. J. 2015, 271, 204-213. [CrossRef]

29. Badawi, M.A.; Negm, N.A.; Kana, M.A.; Hefni, H.H.; Moneem, M.A. Adsorption of aluminum and lead from wastewater by chitosan-tannic acid modified biopolymers: Isotherms, kinetics, thermodynamics and process mechanism. Int. J. Biol. Macromol. 2017, 99, 465-476. [CrossRef] [PubMed]

30. Nazari, M.; Halladj, R. Adsorptive removal of fluoride ions from aqueous solution by using sonochemically synthesized nanomagnesia/alumina adsorbents: An experimental and modeling study. J. Taiwan Inst. Chem. Eng. 2014, 45, 2518-2525. [CrossRef]

31. Peng, C.; Xi, J.; Chen, G.; Feng, Z.; Ke, F.; Ning, J.; Li, D.; Ho, C.T.; Wan, X. Highly selective defluoridation of brick tea infusion by tea waste supported aluminum oxides. J. Sci. Food Agric. 2017, 97, 1509-1516. [CrossRef] [PubMed]

32. Huang, W.; Edenzon, K.; Fernandez, L.; Razmpour, S.; Woodburn, J.; Cebe, P. Nanocomposites of poly (vinylidene fluoride) with multiwalled carbon nanotubes. J. Appl. Polym. Sci. 2010, 115, 3238-3248. [CrossRef]

33. Goldberg, S.; Johnston, C.T. Mechanisms of arsenic adsorption on amorphous oxides evaluated using macroscopic measurements, vibrational spectroscopy, and surface complexation modeling. J. Colloid Interface Sci. 2001, 234, 204-216. [CrossRef] [PubMed]

34. Tossell, J.A. Theoretical studies on arsenic oxide and hydroxide species in minerals and in aqueous solution. Geochim. Cosmochim. Acta 1997, 61, 1613-1623. [CrossRef] 
35. Tang, W.; Su, Y.; Li, Q.; Gao, S.; Shang, J.K. Superparamagnetic magnesium ferrite nanoadsorbent for effective arsenic (III, V) removal and easy magnetic separation. Water Res. 2013, 47, 3624-3634. [CrossRef] [PubMed]

36. Ouma, I.L.; Naidoo, E.B.; Ofomaja, A.E. Thermodynamic, kinetic and spectroscopic investigation of arsenite adsorption mechanism on pine cone-magnetite composite. J. Environ. Chem. Eng. 2018, 6, 5409-5419. [CrossRef]

37. Mahmoud, A.E.D.; Fawzy, M. Bio-based methods for wastewater treatment: Green sorbents. In Phytoremediation; Springer: Cham, Switzerland, 2016.

38. Lagergren, S. Zur theorie der sogenannten adsorption gelosterstoffe. Kungliga svenska vetenskapsakademiens. Handlingar 1898, 24, 1-39.

39. Ho, Y.S.; McKay, G.; Wase, D.A.J.; Forster, C.F. Study of the sorption of divalent metal ions on to peat. Adsorp. Sci. Technol. 2000, 18, 639-650. [CrossRef]

40. Low, M.J.D. Kinetics of chemisorption of gases on solids. Chem. Rev. 1960, 60, 267-312. [CrossRef]

41. Bibi, S.; Farooqi, A.; Hussain, K.; Haider, N. Evaluation of industrial based adsorbents for simultaneous removal of arsenic and fluoride from drinking water. J. Clean. Prod. 2015, 87, 882-896. [CrossRef]

42. Ramos-Vargas, S.; Cortés-Martínez, R. Remoción simultánea de arsénico y fluoruros de soluciones acuosas mediante semillas de guayaba modificadas. In VIII Congreso Internacional de Ingeniería Bioquímica; XIX Congreso Nacional de Ingeniería Bioquímica: Mazatlán, Mexico, 2014. (In Spanish)

43. Rathore, V.K.; Dohare, D.K.; Mondal, P. Competitive adsorption between arsenic and fluoride from binary mixture on chemically treated laterite. J. Environ. Chem. Eng. 2016, 4, 2417-2430. [CrossRef]

44. Qiao, J.; Cui, Z.; Sun, Y.; Hu, Q.; Guan, X. Simultaneous removal of arsenate and fluoride from water by Al-Fe (hydr) oxides. Front. Environ. Sci. Eng. 2014, 8, 169-179. [CrossRef]

45. Nordin, J.P.; Sullivan, D.J.; Phillips, B.L.; Casey, W.H. Mechanisms for fluoride-promoted dissolution of bayerite $\left[\beta-\mathrm{Al}(\mathrm{OH})_{3}(\mathrm{~s})\right]$ and boehmite $[\gamma-\mathrm{AlOOH}]:{ }^{19} \mathrm{~F}-\mathrm{NMR}$ spectroscopy and aqueous surface chemistry. Geochim. Cosmochim. Acta 1999, 63, 3513-3524. [CrossRef]

46. George, S.; Pandit, P.; Gupta, A.B. Residual aluminium in water defluoridated using activated alumina adsorption-Modeling and simulation studies. Water Res. 2010, 44, 3055-3064. [CrossRef] [PubMed]

47. Wu, K.; Liu, T.; Lei, C.; Zhang, F. Evaluation of Al-based nanoparticle-impregnated sawdust as an adsorbent from byproduct for the removal of arsenic (V) from aqueous solutions. Environ. Prog. Sustain. Energy 2017, 36, 1314-1322. [CrossRef]

48. Mohan, D.; Pittman, C.U., Jr. Arsenic removal from water/wastewater using adsorbents-A critical review. J. Hazard. Mater. 2007, 142, 1-53. [CrossRef] [PubMed]

49. Vázquez Mejía, G.; Martínez-Miranda, V.; Fall, C.; Linares-Hernández, I.; Solache-Ríos, M. Comparison of Fe-Al-modified natural materials by an electrochemical method and chemical precipitation for the adsorption of $\mathrm{F}^{-}$and As (V). Environ. Technol. 2016, 37, 558-568. [CrossRef] [PubMed]

50. Brahman, K.D.; Kazi, T.G.; Baig, J.A.; Afridi, H.I.; Arain, S.S.; Saraj, S.; Arain, M.B.; Arain, S.A. Biosorptive removal of inorganic arsenic species and fluoride from aqueous medium by the stem of Tecomella undulate. Chemosphere 2016, 150, 320-328. [CrossRef] [PubMed]

51. Shakoor, M.B.; Niazi, N.K.; Bibi, I.; Shahid, M.; Sharif, F.; Bashir, S.; Shaheen, S.M.; Wang, H.; Tsang, D.C.W.; Ok, Y.S.; et al. Arsenic removal by natural and chemically modified water melon rind in aqueous solutions and groundwater. Sci. Total Environ. 2018, 645, 1444-1455. [CrossRef] [PubMed]

52. Ding, Z.; Xu, X.; Phan, T.; Hu, X.; Nie, G. High adsorption performance for As (III) and As (V) onto novel aluminum-enriched biochar derived from abandoned Tetra Paks. Chemosphere 2018, 208, 800-807. [CrossRef] [PubMed]

53. Ravulapalli, S.; Kunta, R. Defluoridation studies using active carbon derived from the barks of Ficus racemosa plant. J. Fluor. Chem. 2017, 193, 58-66. [CrossRef]

54. Mohammad, A.; Majumder, C.B. Removal of fluoride from synthetic waste water by using "bio-adsorbents". Int. J. Res. Eng. Technol. 2014, 3, 776-785.

(C) 2018 by the authors. Licensee MDPI, Basel, Switzerland. This article is an open access article distributed under the terms and conditions of the Creative Commons Attribution (CC BY) license (http:/ / creativecommons.org/licenses/by/4.0/). 